\title{
Heat wave killings in Pakistan and possible strategies to prevent the future heat wave fatalities
}

\author{
Maria Saleem ${ }^{1}$, Syed Zawar Shah ${ }^{2 *}$ and Shafiq Azam ${ }^{2}$ \\ ${ }^{1}$ Agriculture University Peshawar, Pakistan \\ ${ }^{2}$ University of the Punjab, Pakistan
}

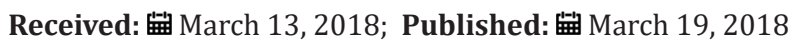

*Corresponding author: Syed Zawar Shah, Centre of Excellence in Molecular Biology, University of the Punjab, Lahore, Pakistan

\begin{abstract}
There is near unanimous scientific consensus that greenhouse gas emissions generated by human activity will change Earth's climate. The recent (globally averaged) warming by $0.5^{\circ} \mathrm{C}$ is partly attributable to such anthropogenic emissions. Climate change will affect human health in many ways-most adversely. Heat waves are the most fatal type of weather situations and they happen irregularly in different countries. Heat waves are well-known in other countries but the people of Pakistan became familiar with it in 2010 when the extremely high temperature was recorded at Mohenjo-Daro, which was the hottest temperature ever recorded in Asia. After this incident heat waves again knocked the boundary of Pakistan in 2015 and at this time it caught attention because it resulted in a lot of deaths due to hyperthermia. Heat waves form when high pressure aloft become stronger and remains over a region for several days up to several weeks. Areas of high population having dense accommodation and poor people are at risk to the adverse effects of heat waves. Government should take steps to prevent deaths by investing in the electrical infrastructure. Besides this, public awareness is also important to minimize the loss.
\end{abstract}

\section{Introduction}

A long period of intensive hot weather along with high rate of humidity is referred to as a heat wave especially in oceanic climate countries. A definition based on Frich et al. [1,2] Heat Wave Duration Index is that a heat wave occurs when the daily maximum temperature of more than five consecutive days exceeds the average maximum temperature by $5^{\circ} \mathrm{C}\left(9^{\circ} \mathrm{F}\right)$, the normal period being 1961 1990. According to the definition given by Glossary of Meteorology, "heat wave is a period of abnormally and uncomfortably hot and usually humid weather" [3]. Heat wave refers to both regular weather variations and to very unusual heat spells that occur once in a century. Warmer climates with increased mean temperatures seems to become more intense, longer lasting, and more frequent in future [1,2]. Intense heat waves have caused disastrous crop failures, thousands of deaths from hyperthermia, and extensive power outages due to excessive use of air conditioning. A heat wave is considered extreme weather and a threat because heat and sunlight together may overheat the human body. Urban areas experience high temperatures than rural because of the "Heat Island" effect. Experts say that this recent heat wave of 2015 in

Pakistan is because of the reason that South Arabian Sea and the Indian Ocean are in phase of convergence which is causing aggravation in temperature of the sea shores and adjoining areas.

\section{History}

Heat waves are the most fatal type of weather situations. The first case was reported in Eastern North America in 1896 and this heat wave killed 1500 people but it also happens at irregular intervals in different countries. According to the Agency for Health care Research and Quality, about 6,200 Americans are hospitalized each summer due to excessive heat, and those at highest risk are poor, uninsured or elderly [4]. In 2003, more than 70,000 Europeans died as a result of the European heat wave [5]. The European heat wave of 2006 was the second giant heat wave to harm the continent in four years, with temperatures rising to $40^{\circ} \mathrm{C}\left(104^{\circ} \mathrm{F}\right)$ in Paris; In Ireland, which has a moderate maritime climate, temperatures of over $32^{\circ} \mathrm{C}\left(90^{\circ} \mathrm{F}\right)$ were reported. Highest average July temperatures were recorded at many locations in Great Britain, Netherlands, Denmark, Sweden and Germany. The past year, 2014, has been 
ranked the warmest year on record, driven by the accumulation of heat-trapping greenhouse gases in the atmosphere. However, 2015 is not too far behind. Nine of the 10 hottest years on record have all occurred in the 21st century.

\section{Extreme weather in Pakistan}

The highest temperature ever recorded in Pakistan is 53.5 ${ }^{\circ} \mathrm{C}\left(128.3^{\circ} \mathrm{F}\right)$ which was recorded in Mohenjo-daro, Sindh on 26 May, 2010. It was also the hottest reliably measured temperature ever recorded on the continent of Asia and the fourth highest temperature ever recorded on earth [6,7].

\section{Record-breaking 2010 summer heat wave}

The hottest temperature ever recorded in Asia and the fourth highest temperature ever recorded in the world was in Mohenjodaro, Sindh at $53.5^{\circ} \mathrm{C}\left(128.3^{\circ} \mathrm{F}\right)$ on May 26, 2010. Twelve cities in Pakistan had temperatures above $50{ }^{\circ} \mathrm{C}\left(122{ }^{\circ} \mathrm{F}\right)$ during the severe heat wave of summer 2010, which lasted from May 22 to May 31, 2010 [8]. On May 27, temperatures higher than $45^{\circ} \mathrm{C}(113$ ${ }^{\circ} \mathrm{F}$ ) harmed areas across Pakistan and at least 18 people died as a result [9]. Also, during the extreme heat wave season, 11 cities experienced their highest ever recorded temperatures of $50{ }^{\circ} \mathrm{C}$ $\left(122^{\circ} \mathrm{F}\right)$ or above, and five cities experienced temperatures of 53 ${ }^{\circ} \mathrm{C}\left(127^{\circ} \mathrm{F}\right) .11$ cities also saw extremes of more than $45^{\circ} \mathrm{C}(113$ $\left.{ }^{\circ} \mathrm{F}\right)$ but below $50^{\circ} \mathrm{C}\left(122^{\circ} \mathrm{F}\right)$. The previous record-temperature for Pakistan and for Asia was on June 12,1919 at $52.8^{\circ} \mathrm{C}\left(127{ }^{\circ} \mathrm{F}\right)$ at Jacobabad $[10,11]$.

\section{5 summer heat wave and death toll in Pakistan}

In Pakistan's Southern areas high temperatures were recorded . The temperature ranged from $49^{\circ} \mathrm{C}\left(120^{\circ} \mathrm{F}\right)$ in Larkana and Sibi to $45^{\circ} \mathrm{C}\left(113^{\circ} \mathrm{F}\right)$ in Karachi. In southern Punjab, $40^{\circ} \mathrm{C}\left(104^{\circ} \mathrm{F}\right)$ was recorded in Multan whereas several areas of the Balochistan province were also affected where temperature reached to $49{ }^{\circ} \mathrm{C}$ $\left(120^{\circ} \mathrm{F}\right)$ in Sibi and Turbat. In the Southern Pakistan, the death toll climbed to 1233 in 2015 because of the severe heat wave. Among them, 260 bodies were never identified. According to the officials, they were either homeless people who sleep rough on the streets or maybe drug addicts [12]. During this heat wave, around 65,000 people were treated in Karachi hospitals because of the heatstroke [13]. Elderly and poor were the worst affected groups. This heat wave was observed during the fasting month of Ramadhan which further worsen the situation along with power cuts.

\section{Recorded temperatures}

Extreme temperatures started to grip Pakistan's southern areas on 18 June 2015, and peaked on 20 June [14,15] (Table 1) By 24 June 2015 , the temperature and death records began to decline; the maximum temperature in Karachi was $37^{\circ} \mathrm{C}\left(98^{\circ} \mathrm{F}\right)$, and officials reported 58 deaths compared to 300 the prior day [16] (Figure 1).

Table 1.

\begin{tabular}{|c|c|c|}
\multicolumn{1}{|c|}{ Date } & Place & Temperature Recorded \\
\hline 20-Jun-15 & Karachi & $45^{\circ} \mathrm{C}\left(113^{\circ} \mathrm{F}\right)$ \\
\hline 20-Jun-15 & Larkana & $49^{\circ} \mathrm{C}\left(120^{\circ} \mathrm{F}\right)$ \\
\hline 20-Jun-15 & Turbat & $49^{\circ} \mathrm{C}\left(120^{\circ} \mathrm{F}\right)$ \\
\hline 20-Jun-15 & Sibi & $49^{\circ} \mathrm{C}\left(120^{\circ} \mathrm{F}\right)$ \\
\hline 20-Jun-15 & Rahim Yar Khan & $43^{\circ} \mathrm{C}\left(109^{\circ} \mathrm{F}\right)$ \\
\hline 20-Jun-15 & Dadu & $44^{\circ} \mathrm{C}\left(111^{\circ} \mathrm{F}\right)$ \\
\hline 20-Jun-15 & Multan & $40^{\circ} \mathrm{C}\left(104^{\circ} \mathrm{F}\right)$ \\
\hline 20-Jun-15 & Nawabshah & $41^{\circ} \mathrm{C}\left(106^{\circ} \mathrm{F}\right)$ \\
\hline 20-Jun-15 & Hyderabad & $42^{\circ} \mathrm{C}\left(108^{\circ} \mathrm{F}\right)$ \\
\hline
\end{tabular}

Figure 1.

\section{How they occur}

Heat waves form when high pressure aloft (from 10,000-25,000 feet $(3,000-7,600$ metres) become stronger and remains over a region for several days up to several weeks. This is common in summer (in both Northern and Southern Hemispheres) as out flux 'follows the sun'. The high pressure area is on the equator side of 
the out flux, in the middle layers of the atmosphere. Summertime weather patterns are generally slower to change than in winter due to which this mid-level high pressure also moves slowly. The air sinks toward the surface under high pressure. This sinking air acts as a dome covering the atmosphere. This cap helps to trap heat instead of allowing it to lift. There is little or no convection without the lift and therefore little or no convective clouds with minimum chances for rain. So, the end product is a constant build-up of heat at the surface that people experience as a heat wave [17].

\section{Health risks}

Our body produces heat, mostly during physical activities. Hot air, sun rays, and hot surfaces also heat up our body. This heat can be lost by contact with cool air and by sweat production, which cools our body as it evaporates. Weather situations play a huge role in how our body maintains its temperature. For example, if it's windy, sweat evaporates faster, which helps to cool us. But high humidity slows down this process, aiding to increased body temperature. Heat illnesses can affect us immediately, and can lead to long-lasting health problems and even death. They are caused by being over-exposed to intense heat especially if we are doing too much for our age and physical condition. Heat illnesses include: heat edema (swelling of hands, feet, and ankles), heat rash, heat cramps (muscle cramps), heat fainting, heat exhaustion and heat stroke. Extreme heat can keep everyone at risk from heat illnesses. Health older adults, infants and young children, people with chronic illnesses (like breathing problems, mental illness, and heart problems), human beings who work in the heat, people who exercise in the heat, homeless people and people with low-income.

\section{Security tips}

There are number of things that people can do to help themselves from heat wave. These include. These include wearing damp clothes which will help lower the body's temperature, sticking one's hands in cold water, placing fans next to windows as this will draw air from outside, which should be cooler, wearing loose clothes, having a lukewarm shower rather than a cold one and fanning the face rather than other parts of the body [12]. Look for side effects of warmth illness, which include: dizziness or swooning, nausea or heaving, headache, rapid breathing and pulse, extreme thirst (dry mouth or sticky salivation), decreased pee with uncommonly dull yellow pee, changes of conduct in kids (like drowsiness or fits). When individual has any of these side effects during amazing warmth, move him to a cool place and beverage fluids immediately.

Water is best. While sitting tight for help - cool the individual immediately by moving them to a cool spot, apply ice-cold water to major areas of their skin or garments, fan the individual however much as could sensibly be expected. Drink a lot of cool fluids (mainly water).Never leave individuals or pets inside a stopped vehicle or in direct daylight. When the outside air temperature is $23^{\circ} \mathrm{C} / 73^{\circ} \mathrm{F}$, the temperature inside a vehicle can be strikingly dangerous - more than $50^{\circ} \mathrm{C} / 122^{\circ} \mathrm{F}$.

\section{Why so many people died in Karachi's heat wave}

Karachi's heat wave resulted in high number of deaths which was the cumulative effect of Ramadan when people fast from dawn to dusk, prolonged electricity shortages, pollution, chronic water shortages and climatic change [12]. A person who survived with heat wave said that "It was difficult to breathe, as if the air had no oxygen". Majority of the people, including the authorities were not aware of the deadly impact of heat wave and no warnings were issued. The provincial government seemed completely unresponsive to this unfolding tragedy. Experts say that this heat wave is the result of phenomenon called "time mover". Scientists warned that heat wave will become more frequent and intense due to the climatic change but government is yet to recognise this impending threat. Many of these deaths could have been avoided if the people were provided with clean drinking water in access and had given early warnings in relation to heat wave [18].

\section{How to prevent future heat wave fatalities in Pakistan}

People of Pakistan are not strange to high temperatures with sizzling hot and humid weather in summer but from the recent killings it is proved that the local government failed to prepare for and respond to the heat waves. Something must be done to overcome this deadly threat which is increasing day by day. Heat Health action plan must be established to raise the awareness of health risks and to train healthcare workers so that they can recognise the signs of heat stress. A coordinated action is needed to prepare for the rising threat and a forecast system needs to be developed that can alert the administration to impending heat waves several days out [18]. Along with that, excessive trees are planted and energy from other key sources must be availed to overcome energy crisis.

\section{Conclusion}

Heat wave resulted in many killings in Pakistan due to the incorrect procedures in place and because of the lack of planning in government and social sector about how to cope with situations like this. During such situations, blackouts are common because of the energy crisis which put hospital patients at risk. We should look for the efficient strategies to counter associated loss. Public must be educated about potential heat related illnesses and preventive measures, early warning systems must be initiated, medical staff should be trained and adaptive measures are promoted.

\section{References}

1. Rignot E, Rivera A, Casassa G (2003) Contribution of the Patagonia icefields of South America to sea level rise. Science 302: 434-437.

2. Malhi Y, Phillips OL (2004) Tropical forests and global atmospheric change: a synthesis. Philos Trans R Soc Lond B Biol Sci 359: 549-555.

3. Robinson, Peter J (2001) "On the Definition of a Heat Wave". Journal of Applied Meteorology (American Meteorological Society) 40(4): 762775. 
4. Most People Struck Down by Summer Heat Are Poor (2008) Newswise, USA.

5. Robine Jean Marie, Cheung Siu Lan, Le Roy Sophie, Van Oyen Herman, Griffiths Clare (2008) Death toll exceeded 70,000 in Europe during the summer of 2003. ComptesRendusBiologies 331(2): 171-178.

6. (2010) Wunder Blog: Weather Underground. Wunderground.com, Georgia.

7. (2010) Extreme Heat wave in Pakistan Pakmet.com.pk, Pakistan.

8. (2010) Record breaking heat in Pakistan". Pakmet.com.pk, Pakistan.

9. (2010) Heatwave kills 18 across Pakistan". PakTribune, Pakistan.

10. Masters Jeff (2010) Asia records its hottest temperature in history; Category 4 Phet threatens Oman. Weather Underground, Jeff Masters WunderBlog, USA.

11. Vidal John, Declan Walsh (2010) Temperatures reach record high in Pakistan. guardian.co.uk, UK.

\section{cC) (i) This work is licensed under Creative Commons Attribution 4.0 License}

To Submit Your Article Click Here : Submit Article

DOI: $10.32474 /$ RRHOAJ.2018.01.000113
12. (2015) Why did so many die in Karachi's heatwave? BBC News, UK.

13. (2015) Pakistan heatwave death toll climbs past 1,200 . Al Jazeera and agencies.

14. (2015) Heat wave: Under scorching sun, Pakistan swelters. The Express Tribune, Pakistan.

15. (2015) Temperature soars to 46, load shedding adds to woes. Geo TV, Pakistan.

16. Imtiaz Saba, Zia ur Rehman (2015) Temperature and Daily Death Toll Fall as Heat Wave Appears to Abate in Pakistan. New York Times, USA.

17. Heat Index. US National Weather Service, USA.

18. Rina Saeed Khan (2015) Is Karachi experiencing climate change?. Pakistan.

Research and Reviews on
Healthcare: Open Access Journal
Assets of Publishing with us
- Global archiving of articles
- Immediate, unrestricted online access
Rigorous Peer Review Process
- Authors Retain Copyrights

